\title{
A FUZZY BASED DECISION SUPPORT SYSTEM FOR AIR CONDITIONER SELECTION AND AN APPLICATION TO TURKISH CONSTRUCTION SECTOR
}

\author{
Tolga Temuçin, Hakan Tozan
}

Original scientific paper In the construction industry, air conditioners (AC) are vital structural segments affecting human's comfort and health directly. In this context selection process for the proper $\mathrm{AC}$ requires the usage of multi-criteria decision making (MCDM) methods due to conflicting criteria such as purchasing and maintenance costs, technical sufficiency, quality of service, performance, etc. This study provides distinct systematic approaches both in fuzzy and crisp environments to deal with the selection problem of appropriate AC and proposes a decision support model helping decision makers in construction sector to assess the potentials of different products. The required data for decision matrices is obtained via a questionnaire administered to specialists as well as deep discussions with experts working in one of the leading construction firms and making use of past studies. An application of the proposed model is also performed in a leading construction company in Turkey.

Keywords: air conditioning industry; construction sector; ELECTRE; fuzzy logic; multi-criteria decision making; TOPSIS

Fuzzy temeljen sustav za pomoć kod donošenja odluke o izboru klima uređaja i primjena u građevinskom sektoru u Turskoj

Izvorni znanstveni rad U građevinarstvu su klima uređaji - air conditioners (AC) bitni konstrukcijski elementi od direktnog utjecaja na udobnost i zdravlje ljudi. U tom kontekstu postupak izbora odgovarajućeg uređaja zahtijeva primjenu metoda za donošenje odluke s više kriterija (MCDM - multi-criteria decision making) zbog kontradiktornih kriterija kao što su kupovni troškovi i troškovi održavanja, zadovoljavajuća tehnička svojstva, kvaliteta upotrebe, radne karakteristike itd. U radu se daju jasni, sustavni pristupi i u fuzzy i u crisp okruženju za izbor odgovarajućeg klima uređaja i predlaže model za pomoć onima u građevinskom sektoru koji donose odluku da procijene mogućnosti raznih proizvoda. Podaci potrebni za matrice donošenja odluke dobivaju se putem upitnika podijeljenih stručnjacima kao i podrobnih razgovora s ekspertima koji rade u jednoj od vodećih građevinskih tvrtki te proučavanjem podataka iz prethodnih istraživanja. Predloženi je model također primijenjen u vodećem građevinskom poduzeću u Turskoj.

Ključne riječi: donošenje odluka s više kriterija; ELECTRE; fuzzy (neizrazita) logika; građevinski sektor; industrija klima uređaja; TOPSIS

\section{Introduction}

Decision making that can be defined as a procedure to find the best alternative among a set of feasible alternatives is a challenging problem because of the increased number of alternatives and conflicting criteria $[1 \div 5]$. Kaya and Kahraman [6] expressed that MCDM is a powerful tool widely used for such complex problems featuring high uncertainty, conflicting objectives, multi interests, and perspectives. According to Li and Love [7], the construction industry is characterized by continual changes, varying technology, and the involvement of numerous operations requiring enormous efforts to manage acceptable outcomes. In this context the illstructured and multi-criteria nature of construction problems supplies a magnificent foundation for MCDM methods to be used widely in the sector $[8,9]$. Eshlaghy and Homayonfar [10] expressed that MCDM is used as a common tool in various projects connected with the construction sector such as Arain and Pheng [11] and Banaitiene et al. [12].

Air conditioning systems are one of the most important segments of the construction sector in which cost, endurance, comfort, and etc. act as conflicting criteria. Wang and Lavan also [13] emphasized the usage of MCDM for selection of proper air-conditioning systems and their subsystems.

The purpose in this study is to propose a decision support model which is helpful in ranking air conditioning systems. Criteria for the model and weights that represent the rate of importance for those criteria were identified via questionnaires administered to specialists, deep discussions with experts, and making use of past studies. The remainder of this study is structured as follows. In the second section, state of the art analysis and, in the third section, research methods are introduced briefly. Afterwards, in the fourth section the proposed DSS is introduced firstly and then a case study is conducted. Finally, a conclusion and further recommendations are highlighted in the last section.

\section{State of the art analysis}

Air conditioning has rapidly grown over the past 50 years, from a luxury to a standard system included in almost every residential building $[14,15]$. The data illustrated in Tab. 1, which was released with the technical report of The Union of Chambers and Commodity Exchanges of Turkey, supports this claim [16].

Table 1 Export and import values for AC industry (USD) [16]

\begin{tabular}{|c|c|c|}
\hline Year & Export values & Import values \\
\hline 2000 & 92253484 & 752996697 \\
\hline 2001 & 120804716 & 562643799 \\
\hline 2002 & 148549430 & 754774089 \\
\hline 2003 & 237714855 & 931141668 \\
\hline 2004 & 337126762 & 1235045391 \\
\hline 2005 & 430826245 & 1399098727 \\
\hline 2006 & 531878901 & 1732997164 \\
\hline 2007 & 781459830 & 2206007842 \\
\hline 2008 & 1124257320 & 2215951376 \\
\hline 2009 & 894718879 & 1646036565 \\
\hline 2010 & 1079823462 & 2460758092 \\
\hline 2011 & 1241141538 & 2774908085 \\
\hline
\end{tabular}

Although MCDM is widely used in the construction sector $[17,18]$ there is only a limited number of studies 
on the AC industry. As a result of the scarcity of published studies concerning the expanding AC industry, it is approved to propose a DSS in the area.

\section{Research Methods: ELECTRE I, TOPSIS, Fuzzy TOPSIS and Fuzzy ELECTRE I \\ 3.1 ELECTRE I}

ELECTRE I was developed by Bernard Roy in 1968 [19]. The basic concept of the method is to deal with the outranking relations by using pair wise comparisons of alternatives with respect to each criterion [20]. In this method, the aim is to find the subset called kernel, the set of alternatives which are accepted to be the best at the end of the method [21], by utilizing the outranking relations of alternatives. That is why the DM has to focus his / her attention to the kernel as it holds the best alternative(s). The algorithm of the method is described as follows:

- Construct Decision (A) and Weight (W) Matrices: This is the step where each alternative defined by $a_{1}$, $a_{2}, \ldots, a_{i}, \ldots, a_{m}$ is evaluated in terms of each criterion defined by $c_{1}, c_{2}, \ldots, c_{j}, \ldots, c_{n}$ to obtain performances $a_{i j}(i=1,2, \ldots, m)(j=1,2, \ldots, n)$, which will eventually enable the creation of the decision matrix. Together with the decision matrix, the weight matrix having the weights defined by $w_{1}, w_{2}, \ldots, w_{j}, \ldots, w_{n}$ for each criterion satisfying $\sum_{j=1}^{n} w_{j}=1$ must also be constituted.

- Construct Normalized Decision Matrix (X): Dependent on the criteria of different units of all kinds, such as $\$$, hour, etc. it can occupy the decision matrix altogether. Existence of this step enables transformation of the decision matrix into a dimensionless form.

- Construct Weighted Normalized Decision Matrix (Y): In this step, different importance weights determined for each criterion are incorporated into the calculation procedure.

- Determine Concordance $\left(C_{i k}\right)$ and Discordance $\left(D_{i k}\right)$ Sets: One classification type for a criterion is to determine whether it is a benefit or a cost criterion. The benefit criterion means that a higher value is better, while for any cost criterion the opposite is valid [22]. In case that the alternative $a$ is compared with the alternative $b$, the discordance set is the one containing the criteria, in which the alternative $a$ is worse than the alternative $b$ and the concordance set is the one containing the remaining criteria.

- Construct Concordance (C) and Discordance (D) Matrices: In case that the alternative $a$ is compared with the alternative $b$, the concordance matrix provides a measure of the outranking character of $a$, while the discordance matrix provides a measure of the outranked character of $a$. These matrices contain values for each alternative pair.

- Construct Dominance Concordance (F) and Dominance Discordance (G) Matrices Construct Total Dominant Matrix (E)

- $\quad$ Determine Importance Sequence of Alternatives

\subsection{TOPSIS}

TOPSIS, which was developed by Yoon and Hwang in 1980 [23], was evolved as an alternative to the ELECTRE I. According to Chu and Lin [24], advantages of this method are the following:

- Computation procedure is simple,

- Method's logic is understandable, and

- Importance weights are incorporated into the procedure.

As a human, DM tries to reach an ideal solution of any problem. The ideal can be described as a perfect example of what something should be like, but that is not likely to really exist. In this respect, Ideal Solution is the choice with best performances in each criterion, which is indeed impossible to come true. However, it is impossible to reach an ideal solution. In a case like this, the choice nearest to the ideal solution must be preferred. The method uses the concepts of Positive Ideal Solution and Negative Ideal Solution in order to determine the best choice. The positive ideal solution is the one maximizing the benefit criterion and minimizing the cost criterion, while for the negative ideal solution the opposite is valid [24]. According to this method the best alternative is the one which is nearest to the positive ideal solution and farthest from the negative ideal solution [25]. The algorithm of the method is described as follows:

- Construct Decision (A) and Weight (W) Matrices

- Construct Normalized Decision Matrix (X)

- $\quad$ Construct Weighted Normalized Decision Matrix (Y)

- Determine Positive (PIS) and Negative (NIS) Ideal Solutions: Dependent on the criterion, the PISs are the ones having the best values in each column while the opposite is valid for NISs.

- Calculate Separation Measures: In this step, the distances of each alternative from negative ideal solution $\left(S_{i}^{-}\right)$and positive ideal solution $\left(S_{i}^{*}\right)$ are calculated.

- Calculate Relative Closeness to the Ideal Solution $\left(C_{i}^{*}\right)$ : Using the distances from $S_{i}^{-}$and $S_{i}^{*}$, the relative closeness to the ideal solution is calculated.

- Rank Preference Order: The alternative with the highest $C_{i}^{*}$ is the best choice.

The details, calculation steps, and basic information on TOPSIS can be found in Temuçin and Tozan et al. [8].

\subsection{Fuzzy sets theory in MCDM}

Fuzzy logic (FL) notion was first introduced by L. A. Zadeh in 1965 [26]. It is a precise logic of imprecision and approximate reasoning [27]. Kaehler [28] denoted that it provides a simple way to arrive to the definite conclusion based upon vague, ambiguous, imprecise, noisy, or missing input information.

Very often in MCDM problems the data are imprecise and fuzzy. Contrary to the crisp set theory, the fuzzy set theory is developed to cope with these kinds of indefiniteness. As a result, fuzzy versions of TOPSIS and ELECTRE I that use the fuzzy set theory concept have emerged. 


\subsubsection{Fuzzy ELECTRE and Fuzzy TOPSIS}

Error rate defined for decision and weight matrices helps to obtain a triangular fuzzy number (TFN) from each crisp number. Considering a TFN formed by a triplet $\left\{\tilde{a}=\left(a_{1}, a_{2}, a_{3}\right)\right\}$, the most extreme values and the middle one can be computed with Eq. (1).

$$
\begin{aligned}
& a_{1}=(\text { crisp data })-(\text { crisp data }) *(\text { error rate } / 100) \\
& a_{2}=(\text { crisp data }) \\
& a_{3}=(\text { crisp data })+(\text { crisp data }) *(\text { error rate } / 100)
\end{aligned}
$$

Steps for fuzzy ELECTRE I and Fuzzy TOPSIS methods are similar to those of ELECTRE I and TOPSIS, respectively [8].

\section{Proposed DSS and a case study for the AC ranking in Turkish construction sector 4.1 Proposed DSS}

Sometimes, environmental conditions are changed by technological methods which are called air conditioners to form a surrounding where a human can study and rest comfortably. The air conditioning cycle used in split air conditioners is shown in Figure 1 and can be broken down into the following stages [29]:

Path 1-Path 2: When low pressure liquid refrigerant reaches the evaporator, it changes its state from a liquid to a gas by absorbing heat from its surroundings. During this process the room in which the air conditioner is located gets cold. Low pressure liquid refrigerant is slightly superheated at the evaporator exit.
Path 2 - Path 3: The superheated vapor enters the compressor where its pressure is raised. In this step, the temperature will also increase, because a proportion of the energy put into the compression process is transferred to the refrigerant.

Path 3 - Path 4: The high pressure superheated gas moves to the condenser. The initial part of the cooling process de-superheats the gas before it is then turned back into liquid. The cooling for this process is usually achieved by using air or water. A further reduction in temperature happens in the pipe work and liquid receiver so that the refrigerant liquid is sub-cooled as it enters the expansion device.

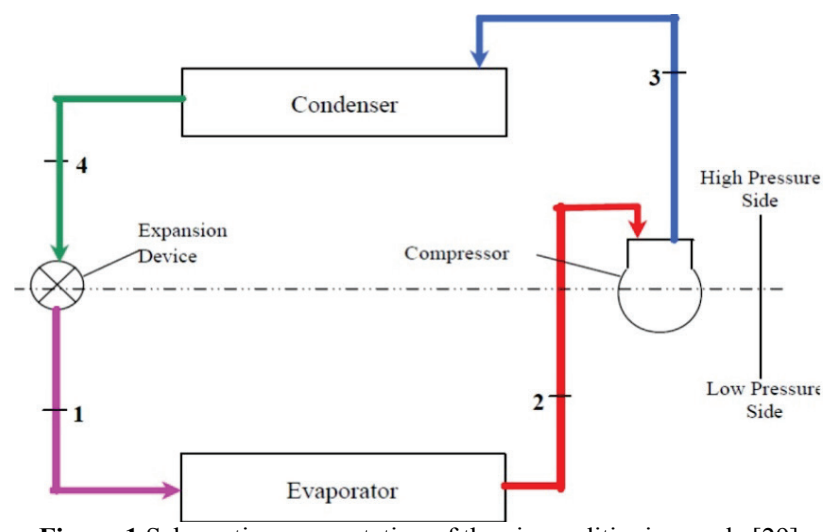

Figure 1 Schematic representation of the air conditioning cycle [29]

Path 4 - Path 1: The high pressure sub-cooled liquid passes through the expansion device, which both reduces its pressure and controls the flow into the evaporator.

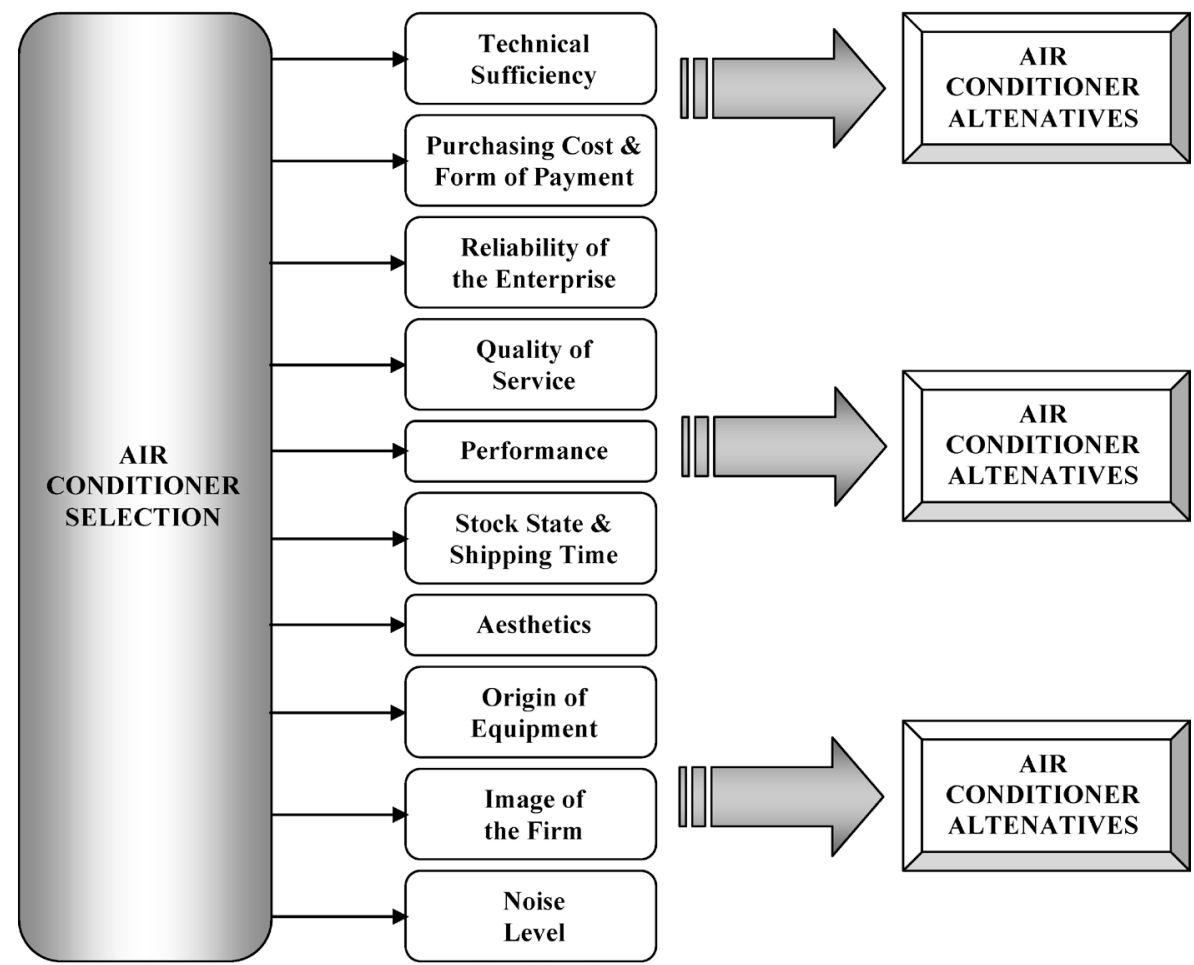

Figure 2 Structure of the air conditioner selection DSS model

The determination of the criteria for the proposed DSS was done via questionnaires filled in by specialists as well as deep discussions with experts working in leading construction firms in Turkey such as AKDENIZ INSŞAAT \& EĞİTIM HİZMETLERİ A.Ş., and also through making use of past studies by Isssan [30], Lee 
[31], and Cho et al. [32]. The AC alternatives used in the proposed model were also determined in the same way.

According to Isisan [30] performance, technical sufficiency, noise, operating costs, purchasing cost, maintenance service, reliability of enterprise, and aesthetics are some criteria that should be used in the comparison of air conditioning systems. Lee [31] and Cho et al. [32] also defined the importance of noise and efficiency in air conditioning systems. Fig. 2 illustrates the skeleton of the proposed model including criteria and alternatives.

\subsection{Case study for the AC ranking in Turkish construction sector}

The determination of the weights concerning each criterion, error rate $(10 \%)$, and performances of alternatives in terms of each criterion was done via a questionnaire filled in by specialists working in Akdeniz İnşaat \& Eğitim Hizmetleri Inc. which is within AĞAOĞLU Corporate Group, one of the leading companies in the construction sector in Turkey. According to FORTUNE 500 TÜRKIYE; the company is the forty fifth largest firm in Turkey and the third largest firm in the construction sector in 2010. At the time of this final procedure, the floor plan of the residence, in which one outside and two inside units of air conditioning system will be located, is taken into account. Fig. 3 illustrates the hierarchical structure of the proposed DSS model for the case study.

At the end of the questionnaire the decision matrix shown in Tab. 2 is obtained.

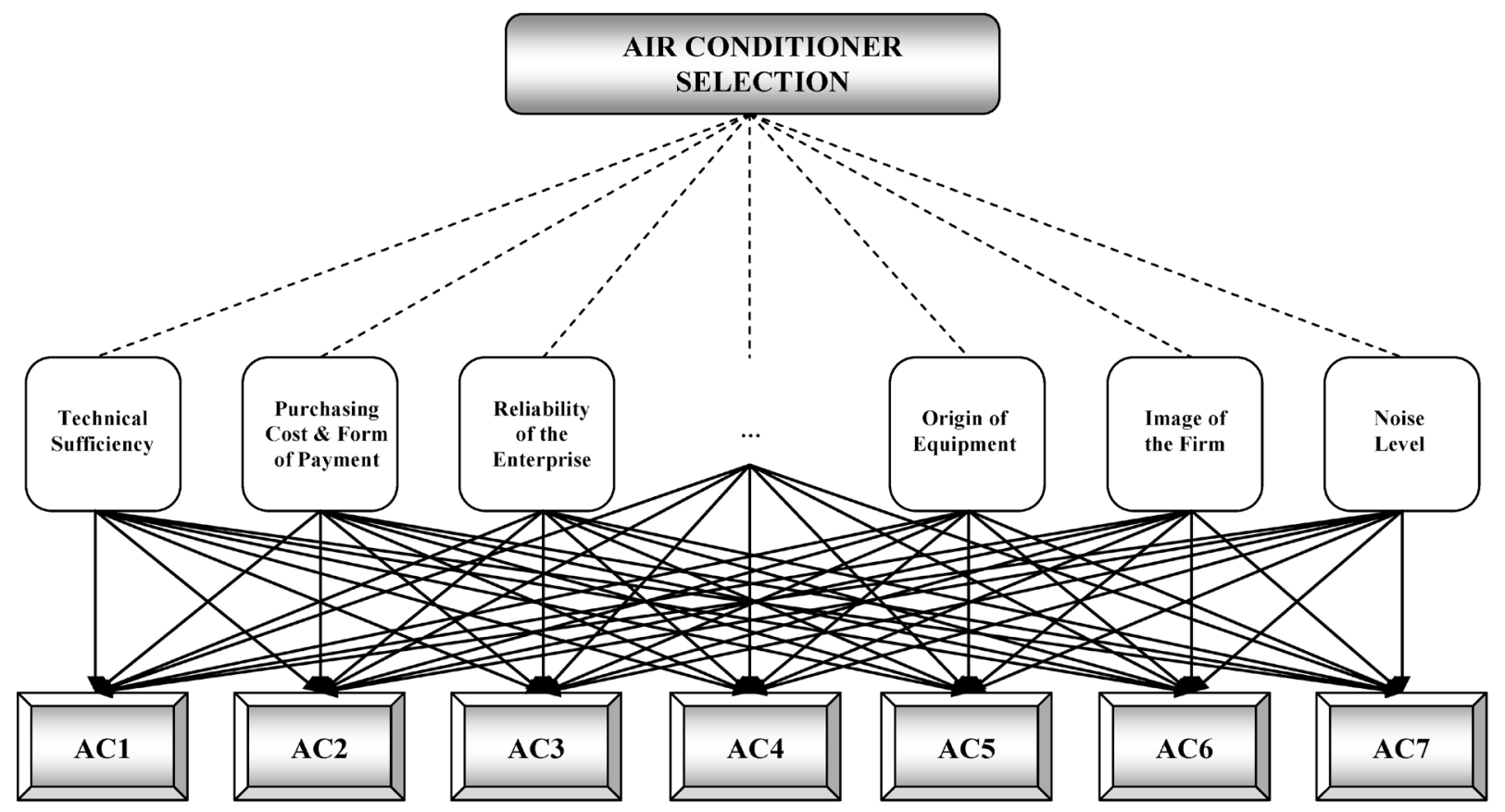

Figure 3 Hierarchical structure of the air conditioner selection DSS model for the case study

Table 2 Decision matrix

\begin{tabular}{|c|c|c|c|c|c|c|c|c|c|c|}
\hline Alt./Cr. & Cr.1 & Cr.2 & Cr.3 & Cr.4 & Cr.5 & Cr.6 & Cr.7 & Cr.8 & Cr.9 & Cr.10 \\
\hline AC 1 & 100 & 85 & 90 & 100 & 80 & 85 & 100 & 85 & 85 & 75 \\
\hline AC 2 & 100 & 90 & 90 & 80 & 70 & 75 & 95 & 75 & 70 \\
\hline AC 3 & 100 & 70 & 75 & 80 & 85 & 80 & 80 & 100 & 70 \\
\hline AC 4 & 100 & 50 & 100 & 75 & 95 & 90 & 70 & 100 & 90 \\
\hline AC 5 & 100 & 75 & 70 & 65 & 75 & 75 & 90 & 75 & 65 & 70 \\
\hline AC 6 & 100 & 65 & 100 & 90 & 90 & 85 & 75 & 100 & 90 & 90 \\
\hline AC 7 & 100 & 100 & 40 & 60 & 65 & 65 & 65 & 75 & 40 & 60 \\
\hline Weight & 85 & 80 & 70 & 70 & 60 & 50 & 90 & 60 & 65 & 55 \\
\hline
\end{tabular}

\section{Conclusion}

There is no element more precious and important to comfort and health than air constituting the largest portion of the human daily diet. Therefore air conditioners have tremendous importance in meeting the requirements of one's daily life. Because of this, the selection process for the most suitable air conditioner is extremely complex. In this study both in crisp and fuzzy environments, ELECTRE I and TOPSIS based hybrid DSS is used to rank alternatives in a matter of seconds. Additionally, a comprehensive DSS model is proposed to assist decision makers in the construction industry in the selection of the right $\mathrm{AC}$ for a specific residential building. A case study was also performed in a leading construction company in Turkey. The required data for the study was obtained via questionnaires given to experts and making use of past studies.

The results reached by four distinct MCDM methods showed that AC 1 is the best alternative among others, as presented in Tab. 3. The general view is that AC 6 has to be thought as the second alternative to be chosen and $\mathrm{AC}$ 7 as the worst one. 
Table 3 Determined ranks for each method

\begin{tabular}{|c|c|c|c|c|}
\hline Alt./Alt. & ELECTRE & TOPSIS & F.TOPSIS & F.ELECTRE \\
\hline $\mathrm{AC} 1$ & 1 & 1 & 1 & 1 \\
\hline $\mathrm{AC} 2$ & 3 & 3 & 4 & 4 \\
\hline $\mathrm{AC} 3$ & 4 & 5 & 5 & 5 \\
\hline $\mathrm{AC} 4$ & 3 & 4 & 3 & 3 \\
\hline $\mathrm{AC} 5$ & 6 & 6 & 6 & 6 \\
\hline $\mathrm{AC} 6$ & 2 & 2 & 2 & 2 \\
\hline $\mathrm{AC} 7$ & 5 & 7 & 7 & 7 \\
\hline
\end{tabular}

\section{References}

[1] Cebi, S.; Kahraman, C. Developing a group decision support system based on fuzzy information axiom. // Knowledge-Based Systems. 23, 1(2010), pp. 3-16. DOI: 10.1016/j.knosys.2009.07.005

[2] Tozan, H. Fuzzy AHP based decision support system for technology selection in abrasive water jet cutting processes. // Tehnički vjesnik - Technical Gazette. 18, 2(2011), pp. 187-191.

[3] Yanar, L.; Tozan, H. A fuzzy hybrid decision support system for interceptor baywatch boat propulsion system. // Tehnički vjesnik - Technical Gazette. 19, 2(2012), pp. 407413.

[4] Chakraborty, P. S.; Sarkar, B.; Majumdar, G. Group decision making for a manufacturing organization considering intensity of preference. // Advances in Production Engineering \& Management. 8, 3(2013), pp. 149-156. DOI: 10.14743/apem2013.3.162

[5] Kaljun, J.; Dolšak, B. Improving Products' Ergonomic Value Using Intelligent Decision Support System. // Strojniski vestnik-Journal of Mechanical Engineering. 58, 4(2012), pp. 271-280. DOI: 10.5545/sv-jme.2011.193

[6] Kaya, T.; Kahraman, C. Multicriteria decision making in energy planning using a modified fuzzy TOPSIS methodology. // Expert Systems with Applications. 38 (2011), pp. 6577-6585. DOI: 10.1016/j.eswa.2010.11.081

[7] Li., H.; Love, P. E. D. Developing a theory of construction problem solving. // Construction Management and Economics, 16, (1998). pp. 721-727. DOI: 10.1080/014461998372015

[8] Temucin, T.; Tozan, H.; Valíček, J.; Harničárová M. A fuzzy based decision support model for mom-traditional machining process selection. // Tehnički vjesnik - Technical Gazette. 20, 5(2013), pp. 787-793.

[9] Turgut B.; Taş H.; Herekoğlu A.; Tozan H.; Vayvay O. A fuzzy AHP based decision support system for disaster center location selection and a case study for Istanbul. // Disaster Prevention and Management. 20, 5(2011), pp. 499520. DOI: 10.1108/096535611111178943

[10] Eshlaghy, A. T.; Homayonfar, M. MCDM methodologies and applications: a literature review from 1999 to 2009. // Research Journal of International Studies. 21, (2011), pp. 86-137.

[11] Arain, F. M.; Pheng, L. S. Knowledge-based decision support system for management of variation orders for institutional building projects. // Automation in Construction. 15, (2006), pp. 272-291. DOl: 10.1016/j.autcon.2005.06.005

[12] Banaitiene, N.; Banaitis, A.; Kaklauskas, A.; Zavadskas, E. $\mathrm{K}$. Evaluating the life cycle of a building: a multivariant and multiple criteria approach. // Omega. 36 (2008), pp. 429-441. DOI: 10.1016/j.omega.2005.10.010

[13] Wang, S. K.; Lavan, Z. Air-conditioning and refrigeration Mechanical engineering handbook. Boca Raton: CRC Press LLC, 1999.

[14] Jeong, W. B.; Han, H. S.; Mo, J. Y.; Lee, J. K. Experimental study of the effects of the cycle characteristics on the refrigerant-induced noise in system air-conditioner. // Journal of Mechanical Science and
Technology. 21, (2007), pp. 1112-1119. DOl: 10.1007/BF03027661

[15] Kreider, J. F. Handbook of heating, ventilation, and air conditioning. Boca Raton: CRC Press LLC, 2000. DOl: 10.1201/9781420036466

[16] Türkiye Odalar ve Borsalar Birliği (2011) Türkiye iklimlendirme meclisi sektör raporu. The Union of Chambers and Commodity Exchanges of Turkey. URL: http://www.tobb.org.tr/Documents/yayinlar/TOBB_iklimle ndirme_raporu_2012.pdf (15.06.2014)

[17] Cristóbal, J. R. Contractor selection using multi-criteria decision-making methods. // Journal of Construction Engineering and Management. 138, (2012), pp. 751-758. DOI: 10.1061/(ASCE)CO.1943-7862.0000488

[18] Xia, B.; Chan, A.; Yeung, J. Developing a fuzzy multicriteria decision-making model for selecting designbuild operational variations. // Journal of Construction Engineering and Management. 137, (2011), pp. 1176-1184. DOI: $10.1061 /(A S C E) C 0.1943-7862.0000381$

[19] Roy, B. Classement et choix en presence de points de vue multiples (la methode ELECTRE). // RIRO. 8, (1968), pp. $57-75$.

[20] Triantaphyllou, E. Multi-criteria decision making methods: a comparative study (Applied optimization). Springer, Boston, 2000. DOI: 10.1007/978-1-4757-3157-6

[21] Vincke, P. Multicriteria decision aid. West Sussex, England, 1992.

[22] Krohling, R. A.; Campanharo, V. C. Fuzzy TOPSIS for group decision making: a case study for accidents with oil spill in the sea. // Expert Systems with Applications. 38 (2011), pp. 4190-4197. DOl: 10.1016/j.eswa.2010.09.081

[23] Hwang, C. L.; Lai, Y. J; Liu, T. Y. A new approach for multiple objective decision making. // Computers \& Operations Research. 20, (1993), pp. 889-899. DOI: 10.1016/0305-0548(93)90109-V

[24] Chu, T. C.; Lin, Y. C. A fuzzy TOPSIS method for robot selection // The International Journal of Advanced Manufacturing Technology. 21, 4(2003) pp. 284-290. DOl: $10.1007 /$ s001700300033

[25] Ertuğrul, İ.; Karakaşoğlu, N. Performance evaluation of Turkish cement firms with fuzzy analytic hierarchy process and TOPSIS methods. // Expert Systems with Applications 36 (2009), pp. 702-715. DOI: 10.1016/j.eswa.2007.10.014

[26] Zadeh, L. A. Fuzzy sets. // Information and Control. 8 (1965), pp. 338-353. DOI: 10.1016/S0019-9958(65)90241-X

[27] Zadeh, L. A. Is there a need for fuzzy logic? // Information Sciences. 178, (2008), pp. 2751-2779. DOl: 10.1016/j.ins.2008.02.012

[28] Kaehler, S. D. Fuzzy logic tutorial-an introduction. The newsletter of the Seattle Robotics Society. URL: http://www.seattlerobotics.org/encoder/mar98/fuz/flindex.h tml.pdf. (25. 06. 2014)

[29] National Productivity Council, India (2006). Refrigeration and air conditioning. URL: http://www.retscreen.net/ fichier.php/893/Refrigeration\%20and\%20Air\%20Condition ing.pdf. (28.05.2014)

[30] Isısan no. 361. Yüksek yapilarda tesisat. Isısan çalışmaları, Istanbul, 2007.

[31] Lee, J. K. Identification of noise sources in scroll compressor for air-conditioner. // KSME International Journal. 14 (2000), pp. 597-604.

[32] Cho, E.; Manyeong, H.; Chang, S.; Hwang, Y. Variable fuzzy control for heat pump operation. // Journal of Mechanical Science and Technology. 25 (2011), pp. 201208. DOI: $10.1007 /$ s12206-010-1105-x 


\section{Authors' addresses}

\section{Tolga Temuçin}

Department of Industrial Engineering,

Turkish Naval Academy,

34942 Tuzla, Istanbul, Turkey

Hakan Tozan (Corresponding Author)

Department of Industrial Engineering,

Piri Reis University,

34942 Tuzla, Istanbul, Turkey

E-mail: e.hakan.t@gmail.com

E-mail: htozan@dho.edu.t 